\title{
Effects of Intermittent Hypoxia on Cytokine Expression Involved in Insulin Resistance
}

\author{
Tomoko Uchiyama $^{1,2, *}$, Hiroyo Ota ${ }^{3}$, Chiho Ohbayashi $^{2}$ and Shin Takasawa ${ }^{1}$ (D) \\ 1 Department of Biochemistry, Nara Medical University, Kashihara 634-8521, Japan; shintksw@naramed-u.ac.jp \\ 2 Department of Diagnostic Pathology, Nara Medical University, Kashihara 634-8522, Japan; \\ ohbayashi@naramed-u.ac.jp \\ 3 Department of Respiratory Medicine, Nara Medical University, Kashihara 634-8522, Japan; \\ hiroyon@naramed-u.ac.jp \\ * Correspondence: uchiyama0403@naramed-u.ac.jp; Tel.: +81-744-22-3051
}

Citation: Uchiyama, T.; Ota, H.; Ohbayashi, C.; Takasawa, S. Effects of Intermittent Hypoxia on Cytokine Expression Involved in Insulin Resistance. Int. J. Mol. Sci. 2021, 22, 12898. https://doi.org/10.3390/ ijms222312898

Academic Editor: Ismail Laher

Received: 10 November 2021 Accepted: 26 November 2021 Published: 29 November 2021

Publisher's Note: MDPI stays neutra with regard to jurisdictional claims in published maps and institutional affiliations.

Copyright: (c) 2021 by the authors. Licensee MDPI, Basel, Switzerland. This article is an open access article distributed under the terms and conditions of the Creative Commons Attribution (CC BY) license (https:// creativecommons.org/licenses/by/ $4.0 /)$.
Abstract: Sleep apnea syndrome (SAS) is a prevalent disorder characterized by recurrent apnea or hypoxia episodes leading to intermittent hypoxia $(\mathrm{IH})$ and arousals during sleep. Currently, the relationship between SAS and metabolic diseases is being actively analyzed, and SAS is considered to be an independent risk factor for the development and progression of insulin resistance/type 2 diabetes (T2DM). Accumulating evidence suggests that the short cycles of decreased oxygen saturation and rapid reoxygenation, a typical feature of SAS, contribute to the development of glucose intolerance and insulin resistance. In addition to $\mathrm{IH}$, several pathological conditions may also contribute to insulin resistance, including sympathetic nervous system hyperactivity, oxidative stress, vascular endothelial dysfunction, and the activation of inflammatory cytokines. However, the detailed mechanism by which IH induces insulin resistance in SAS patients has not been fully revealed. We have previously reported that $\mathrm{IH}$ stress may exacerbate insulin resistance/T2DM, especially in hepatocytes, adipocytes, and skeletal muscle cells, by causing abnormal cytokine expression/secretion from each cell. Adipose tissues, skeletal muscle, and the liver are the main endocrine organs producing hepatokines, adipokines, and myokines, respectively. In this review, we focus on the effect of IH on hepatokine, adipokine, and myokine expression.

Keywords: intermittent hypoxia; sleep apnea syndrome; insulin resistance; hepatokines; adipokines; myokines

\section{Introduction}

Sleep apnea syndrome (SAS) is a common disorder that causes repeated apnea and hypopnea due to the obstruction of the upper airway during sleep, and it occurs in about $13-33 \%$ of men and $5-19 \%$ of women [1,2]. Repeated nocturnal obstruction of the upper airways, a characteristic of SAS, lead to the following physiological effects: fluctuating intrathoracic pressure, sleep fragmentation, hypercapnia, and intermittent hypoxia (IH) [3]. The involvement of these pathologies can lead to chronic diseases of multiple organs. A number of conditions may occur including atherosclerosis, cardiovascular disease, cerebrovascular disease, immunodeficiency, and metabolic abnormalities (pancreatic $\beta$ cell dysfunction, insulin resistance, and increased free-fatty acid [FFA]) may occur [4-11].

In this review, we focus especially on IH because SAS patients are exposed to IH to repeat anoxia periodically by night. $\mathrm{IH}$ induces ischemia-reperfusion (I/R) injury due to a fluctuating situation where hypoxia and reoxygenation occur repeatedly [12]. $\mathrm{IH}$ is a key manifestation of SAS and is thought to initiate a cascade of pathological conditions characterized by sympathetic activation, mitochondrial dysfunction, inflammation, oxidative stress, endothelial dysfunction, and metabolic disorders $[3,11,13]$. SAS patients may display one or more symptoms including fragmented sleep, snoring, excessive daytime sleepiness, fatigue, high blood pressure, depression, and loss of concentration. 
SAS and type 2 diabetes (T2DM) are known to be closely associated with each other. About $15-30 \%$ of SAS patients have T2DM, and the majority of T2DM patients also suffer from obstructive sleep apnea $[14,15]$. Perhaps the most important risk factor for SAS is obesity; however, only about $60-70 \%$ of sleep apnea patients are obese $[3,16]$. The association between SAS and insulin resistance is independent of other factors such as obesity, age, and sex [14,17-21], and IH itself is considered to be a risk factor for insulin resistance/T2DM [5,7,16,19,22-25]. In recent years, Michalek-Zrabkowska et al. investigated the relationship between the severity of SAS without comorbid T2DM and insulin resistance. They concluded that even in the absence of T2DM comorbidity, there is the suggestion of an association with insulin resistance in patients with moderate to severe SAS. Similar findings have been reported in other studies [17,26].

Chronic IH with reoxygenation induces a variety of pathogenesis similar to I/R injury and is thought to play a major role in the diseases caused by SAS [27]. Additionally, various mechanisms leading to glucose intolerance via IH have been reported: sympathetic activation due to hypoxic stress, and pancreatic $\beta$ cell dysfunction because of oxidative stress, and the involvement of inflammatory cytokines [22,24]. Other organs including the liver [5,19], adipose tissue [7,19,28-30], skeletal muscle [31], the central nervous system [32], and the gastrointestinal tract $[25,32]$ are considered to be associated with glucose intolerance/insulin resistance due to $\mathrm{IH}$. A direct effect of $\mathrm{IH}$ is an oxidative imbalance in the production of reactive oxygen species (ROS) and the activation of the inflammatory cascade by increased proinflammatory and anti-inflammatory cytokines; for example, tumor necrosis factor- $\alpha$ (TNF- $\alpha$ ), interleukin (IL)-1, and IL-6 are well known. However, many details remain to be clarified about the expression of cytokines under the influence of $\mathrm{IH}$, including the organs of origin and their effects [33].

The relationship between IH and cytokine secretion has been reported not only in relation to insulin resistance and glucose intolerance, which is reviewed in this article, but also in relation to abnormal cytokine secretion associated with cardiovascular and renal diseases, nasal mucosal injury, and inflammation of the upper respiratory tract [34-37]. Since we previously investigated the way in which IH induces impaired insulin secretion/insulin resistance in in vitro experimental systems using pancreatic $\beta$ cells, neuronal cells, hepatocytes, adipocytes, skeletal muscle cells, and cardiomyocytes $[5,7,19,25,32,38]$, in this review, we focus on how IH induces insulin resistance.

Specifically, we describe changes in cytokines secreted by organs affected by $\mathrm{IH}$, particularly the liver (hepatokines), adipose tissue (adipokines), and skeletal muscle (myokines), and their relationship to insulin resistance.

\section{Intermittent Hypoxia and Cytokines}

\subsection{Intermittent Hypoxia and Hepatokines}

It has long been known that there is a close relationship between glucose intolerance and liver disease. In the insulin-resistant state, lipolysis in adipose tissue is enhanced, leading to increased FFA in the blood and increased FFA influx into the liver. The pancreatic $\beta$ cells compensatively increase insulin synthesis and secretion, resulting in hyperinsulinemia and increased synthesis of new fatty acids in the liver, leading to a nonalcoholic fatty liver disease (NAFLD). The excessive accumulation of triglycerides in the liver induces oxidative stress and inflammation, leading to the development of nonalcoholic steatohepatitis (NASH). In addition, abnormalities in hepatic lipid metabolism caused by insulin resistance lead to increased secretion of atherosclerosis-inducing lipoprotein abnormalities, inflammatory cytokines, and blood clot promoting factor, which promote atherosclerosis and create high-risk conditions for cardiovascular diseases [8,39].

Obstructive sleep apnea syndrome (OSAS) has recently been linked to NAFLD, the most common chronic liver disease in the world, which is found in about $25 \%$ of the general adult population and up to $75 \%$ of obese people [3,40,41]. According to some studies, chronic IH in patients with OSAS may itself cause liver injury, inflammation, and fibrosis, promoting the development of NAFLD and progression from lipidosis to 
steatohepatitis, cirrhosis, and hepatocellular carcinoma. In patients with NAFLD, IH may cause liver disease indirectly by promoting inflammation and insulin resistance and directly by promoting the production of inflammatory cytokines and metabolic abnormalities in hepatocytes [3,42-47].

A few studies investigated the relationship between $\mathrm{IH}$ and cytokines released from the liver (Figure 1). Briancon-Marjollet et al. investigated the respective effects of obesity and IH on inflammatory and cardiometabolic state in rats by exposing lean and obese rats to normoxic conditions or chronic IH and evaluating their serum leptin (LEP), adiponectin (ADIPOQ), hepatic cytokines, nuclear factor- $\mathrm{kB}$ (NF- $\mathrm{kB}$ ) activity, and cardiac endothelin-1 levels. The results showed that the levels of IL- 6 and TNF- $\alpha$ in the liver were elevated in lean rats exposed to $\mathrm{IH}$ [21]. Mesarwi et al. published the following research findings on the association of IH with the progression of NAFLD. NAFLD with steatohepatitis was induced in mice with the hepatocyte-specific deletion of hypoxia-inducible factor (Hif) $1 \alpha$ and in wild-type control mice. The mice were then divided into those with IH and a control group. The HIF $1 \alpha$-deficient mice showed less weight gain and improved fasting blood glucose and insulin resistance. The collagen in the liver increased in the IH group and decreased in the HIF $1 \alpha$-deficient mice. Based on these results, they concluded that HIF-1 signaling worsens the metabolic profile, accelerates the progression of NAFLD, and exacerbates liver fibrosis [48]. The activation of HIF-1 under IH is thought to occur as a result of severe hypoxemia or the excessive production of ROS during the hypoxia-reoxygenation associated with apnea-hypopnea [49]. Zhou et al. investigated the association between NAFLD and SAS in children, using a mouse model divided into Western diet (WD) and control groups and an IH and room air group for 6-12 weeks. The results showed that the WD and IH groups resembled the histological characteristics of pediatric NASH. In addition, the levels of IL- $1 \beta$, IL- 6 , and IL-18 were elevated in the WD and IH groups, suggesting that they promote the inflammatory response in the liver [46].

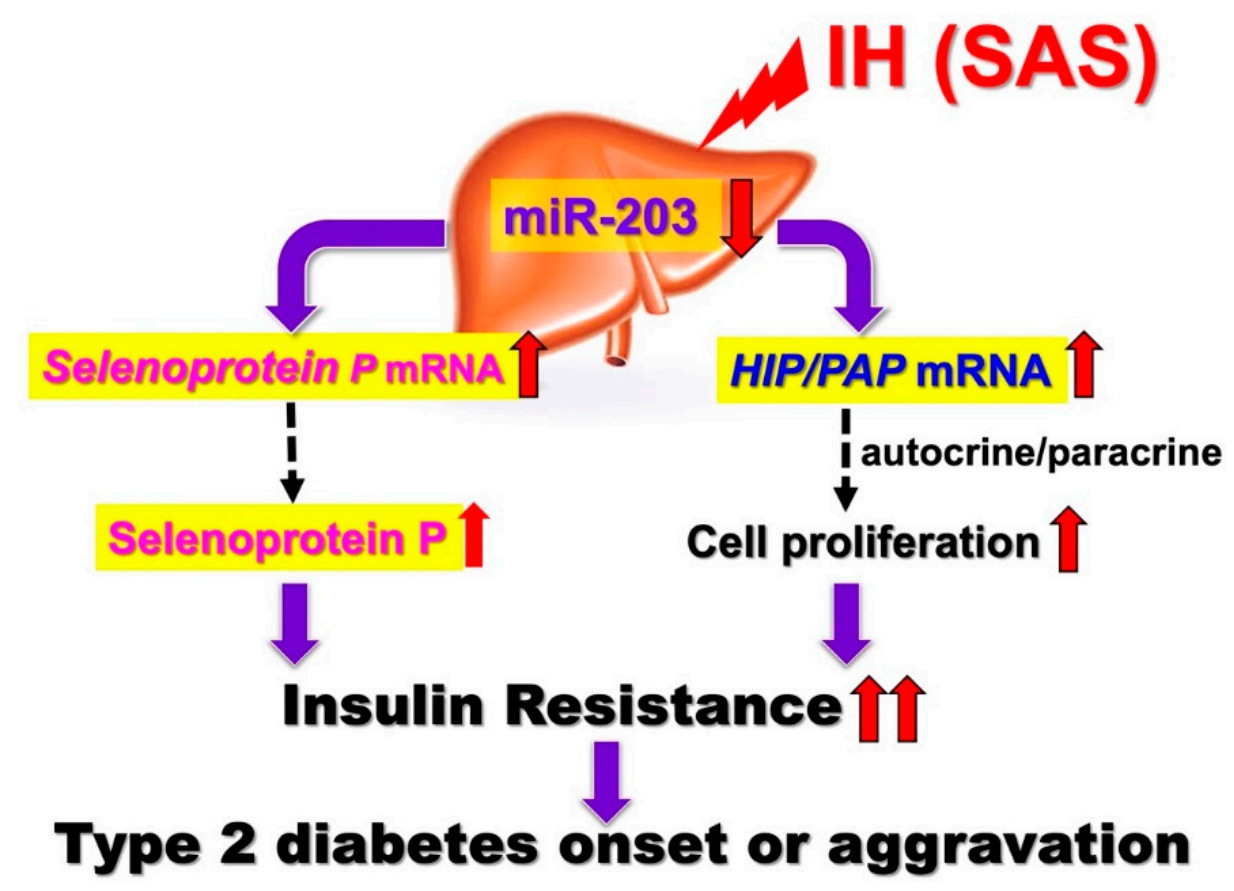

Figure 1. IH-induced upregulation of SeP and HIP/PAP via downregulation of miR-203. IH stress upregulates the levels of $\mathrm{SeP}$ in human hepatocytes to accelerate insulin resistance and upregulates the levels of HIP/PAP mRNAs to cause such hepatocytes to proliferate, via the miR-203 mediated mechanism. [5]. In SAS patients, it is suggested that the upregulation of SeP plays a role in worsening insulin resistance. In addition, overexpression of HIP/PAP could cause such hepatocytes to proliferate in SAS patients, leading to decreased insulin sensitivity. Red up and down arrows mean increment and decrease, respectively. 
Recently, as with adipose tissue, the pancreas, and skeletal muscle, the liver has been recognized as an endocrine organ that secretes a protein known as hepatokine, a liver-derived factor that can signal and transmit to distant tissues and affect glucose metabolism. The liver senses nutrient excess and deficiency and secretes hepatokine and liver-derived factors to regulate nutrient availability to peripheral tissues and the central nervous system $[8,50]$. The relationship between hepatokine secreted by the liver and insulin resistance has been reported, and we examined the effects of $\mathrm{IH}$ on hepatokine expression and hepatocyte proliferation in vitro. Selenoprotein P (SeP encoded by the SEPP1 or SELENOP gene) is a liver-derived selenium carrier protein that is closely related to glucose metabolism. SeP blood levels are known to be high in patients with NAFLD, obesity, and diabetes, and elevated SeP levels are thought to be involved in insulin resistance $[46,51,52]$. Our in vitro study revealed that the gene expression of SeP and hepatocarcinoma-intestine-pancreas/pancreatitis-associated protein (HIP/PAP) were increased via the downregulation of the miR-203 level in IH-treated hepatocytes. The correlation between $\mathrm{IH}$ and epigenetic regulation is discussed below. We also studied the angiopoietin-like protein (ANGPTL) 6, 8, sex hormone-binding globulin (SHBG), fibroblast growth factor (FGF21), leukocyte cell-derived chemotaxin (LECT) 2, and alpha-2-HS-glycoprotein (AHSG) mRNA levels in IH-treated hepatocytes, and we observed no significant change common to all the analyzed hepatocytes [5]. There are a few studies on IH and hepatokine secretion aside from ours, especially in in vitro experimental systems.

The regenerating gene (Reg) was identified in regenerating islets [53-55] and a Reg gene product-Reg protein-acts as a growth factor and promotes cell proliferation and regeneration $[53,56,57]$. In humans, five functional Reg family genes (REG I $\alpha$, REG I $\beta$, REG III, HIP/PAP, and REG IV) have been isolated. For several cells, it has been suggested that Reg family proteins are involved in cellular proliferation $[53,55]$. Ota et al. reported that $\mathrm{IH}$ stress stimulates pancreatic $\beta$ cell proliferation via the up-regulation of Reg family mRNAs and may cause hyperinsulinemia, which makes patients more obese [24]. However, the direct effects of IH on hepatocyte proliferation and the IH-induced changes in Reg family gene expression in hepatocytes remain unknown. We analyzed the changes of REG family gene expression in human hepatocytes by IH. The mRNA levels of HIP/PAP were significantly increased in IH-treated human hepatocytes [5]. Meanwhile, the mRNA levels of the other REG family members (REG I $\alpha$, REG I $\beta$, REG III, and REG IV) were not increased. Human hepatocytes (HepG2, JHH5, and JHH7 cells) were exposed to normoxia or IH for $24 \mathrm{~h}$. HIP/PAP is originally found as a gene overexpressed in liver carcinoma [58] and the pancreas during the acute phase of pancreatitis [59]. Recent HIP/PAP transgenic/knockout mouse experiments [60-62] revealed that it is an autocrine/paracrine mitogenic factor, accelerating liver regeneration. HIP/PAP promotes cell proliferation in hepatocytes by protecting them from apoptosis and acting as a mitogenic factor [60,62]. After the IH treatment of HepG2 cells, cell viability was determined by WST- 8 assay. HepG2 cell proliferation was significantly increased by IH. Furthermore, the RNA interference of HIP/PAP inhibited HepG2 cell proliferation measured by WST-8 assay, whereas the interference of other REG family genes such as REG I $\alpha$ did not. These results indicate that HIP/PAP, upregulated by $\mathrm{IH}$, works as an autocrine/paracrine growth factor in hepatocyte proliferation. In addition, the IH-induced upregulation of SeP and HIP/PAP was revealed to be mediated via the downregulation of miR-203 in hepatocytes [5]. In SAS patients, it is suggested that the upregulation of SeP plays a role in worsening insulin resistance (Figure 1).

In addition, the overexpression of HIP/PAP could cause such hepatocytes to proliferate in SAS patients, leading to decreased insulin sensitivity. Moreover, Takeda et al. recently reported that the expression of renin in juxtaglomerular cells was significantly increased in response to IH stimulation via the downregulation of miR-203 [63]. The most common complications in SAS patients are hypertension and diabetes, and $\mathrm{IH}$, caused by SAS, reduced miR-203 in hepatocytes [5] and juxtaglomerular cells [63], resulting in increased Sep in hepatocytes, a diabetogenic hepatokine, and renin in juxtaglomerular cells, which induces hypertension, simultaneously. 


\subsection{Intermittent Hypoxia and Adipokines}

Adipose tissue is a complex tissue composed of preadipocytes, adipocytes, and interstitial vascular cells and is one of the major organs that contribute to worsening insulin resistance through inflammation and subsequent impaired function. It has long been known that the inflammation and dysfunction of adipose tissue play a pivotal role in the pathogenesis of diabetes. Adipocytes not only convert excess energy into triglycerides and store them but also express and secrete adipokines as endocrine organs to control and regulate the metabolism of the whole body. Numerous studies have been undertaken on the mechanisms of adipose tissue dysfunction in obese patients. In obesity, adipocytes hyperplasia and hypertrophy may occur $[16,30,64]$; however, obesity not only leads to increased fat storage but also to the abnormal function of adipose tissue as an endocrine organ. Adipocyte hypertrophy leads to functional abnormalities and inflammation, resulting in insulin resistance and immune cell infiltration, localized hypoxia, and fibrosis. Following the infiltration of CD8-positive cytotoxic $\mathrm{T}$ cells and the phenotypic change to M1 macrophages, inflammatory adipokines including TNF- $\alpha$, IL-6, and RETN are produced, leading to insulin resistance $[16,30,65,66]$. Additionally, hypoxia is thought to be an important factor in adipose tissue dysfunction in obesity. Continued adipocyte hypertrophy leads to local hypoxia and the activation of the hypoxia-inducible transcription factors, in particular HIF-1, which is regarded as the key molecule for signaling the cellular response to low oxygen levels, thus contributing to dysfunctions and metabolic disorders in adipocytes [67].

Previous studies conducted under IH conditions have reported a decrease in mass and cell shrinkage in adipocytes $[30,68,69]$. Although the adipocyte morphology under obese and IH-exposed conditions may differ, some of the dysfunction mechanisms are common to both $[68,70]$. The mechanism of inflammatory cell infiltration and other mechanisms (such as sympathetic activation and the exacerbation of oxidative stress) are assumed to be common pathways. Due to sympathetic activation, IH cause an increase in blood catecholamines [71], which in turn causes lipolysis and produces FFA, leading to insulin resistance in skeletal muscle and liver cells [72,73]. The chronic elevation of FFA levels has an adverse effect on glucose homeostasis, called lipotoxicity [74]. In addition, in the IH environment, HIF activation by adipose tissue hypoxia has been reported to worsen insulin sensitivity [68], and HIF-1 $\alpha$ protein expression in the blood is reportedly significantly elevated in SAS patients $[75,76]$. Some reports suggest that HIF- 1 is activated in sustained hypoxia (SH), but not in $\mathrm{IH}$, and that inflammatory pathways are selectively activated [77]. In the IH environment, both HIF- 1 and NF- $\mathrm{KB}$ are activated, leading to changes in gene expression. Since HIF-1 is a direct target, such as being transcriptionally regulated by NF- $\mathrm{kB}$, and TNF- $\alpha$ is also regulated by NF- $\mathrm{kB}$, it is possible that crosstalk between HIF-1 and NF-KB is associated with cytokine abnormalities under IH, but the detailed mechanism is not known [77,78]. As described above, there are several possible mechanisms by which $\mathrm{IH}$ induces insulin resistance and not all of them have been elucidated. We conducted research focusing on adipokines.

Adipokines are multiple hormones, cytokines, chemokines, and other proteins secreted by adipocytes in white adipose tissue [30]. Some adipokines are specific to adipocytes, and some are not. More than 50 types of adipokines have been identified to date, including TNF- $\alpha$ and IL-6, which are known to be factors that increase the risk of diabetes and cardiovascular disease [28-30]. The most common adipokines involved in insulin resistance include leptin (LEP), which is involved in appetite control and hypersensitivity to insulin, ADIPOQ, which promotes glucose uptake in skeletal muscle and liver, resistin (RETN), which exacerbates insulin resistance, and C-C motif chemokine ligand 2 (CCL2), which is involved in immunoregulatory and inflammatory processes and is a critical factor for monocyte infiltration $[28,30,67,79,80]$, ANGPTL, which regulates glucose homeostasis, lipid metabolism, and insulin sensitivity [49,81], plasminogen activator inhibitor-1 (PAI-1), and vascular endothelial growth factor (VEGF), which is linked to the inflammatory response [67]. 
The detailed mechanism of association adipokines with SAS remains unclear. Recently, it was reported that FFA and inflammatory mediators such as TNF- $\alpha$ in serum are elevated in SAS patients and mice in an experimental IH environment, and several in vivo studies reported that $\mathrm{IH}$ causes adipose tissue inflammation and insulin resistance [68], suggesting that IH may enhance inflammation and dysfunction in adipose tissue [13,16].

Recently, we investigated the expression and regulation mechanism of adipokines by employing IH exposure. Therefore, to clarify the mechanism by which $\mathrm{IH}$ induces inflammation in adipose tissue and exacerbates insulin resistance, we examined the effects of IH exposure on TNF- $\alpha$, IL-6, etc. A total of seven molecules were measured: six adipokines (ADIPOQ, RETN, LEP, CCL2, TNF- $\alpha$, and IL-6), which are molecules involved in insulin resistance or whose expression is expected to be altered under IH conditions, and uncoupling protein-1 (UCP-1), which is secreted by brown adipocytes and promotes heat production. The mRNA levels of RETN, TNF- $\alpha$, and CCL2 were shown to be increased in mouse 3T3-L1 and human SW872 adipocytes by IH exposure. These results suggest that IH in SAS patients is associated with adipocyte inflammation and the worsening of insulin resistance. We further investigated the mechanism by which IH increases the mRNA levels of adipokines such as RETN, TNF $\alpha$, and CCL2, and found a possible post-transcriptional regulation by miR-452 [7,19]. As shown in Figure 2, the abnormal secretion of TNF- $\alpha$, IL-6, and CCL2, etc., is suggested in adipose tissue under IH conditions, including in our study. Ge et al. have shown that macrophages accumulate in adipose tissue when lean mice are exposed to IH and in obese mice [82]. CCL2 may induce monocytes into adipose tissue and induce inflammation in an IH environment. Although not all SAS patients are obese, exposure to IH may exacerbate insulin resistance by a mechanism similar to that found with obesity under conditions involving adipokines. Recently, Akasaka et al. reported that advanced glycation endproduct, high-mobility group box 1, and lipopolysaccharide in pregnant women upregulate the expression of IL-6 and CCL2 in adipocytes, leading to systemic inflammation such as preeclampsia/hypertensive disorders of pregnancy [19]. As an association between sleep-disordered breathing, gestational hypertension, and preeclampsia has been demonstrated [83-85], CCL2 expressed and secreted from patient adipocytes may link between SAS and hypertensive disorders of pregnancy/gestational diabetes.

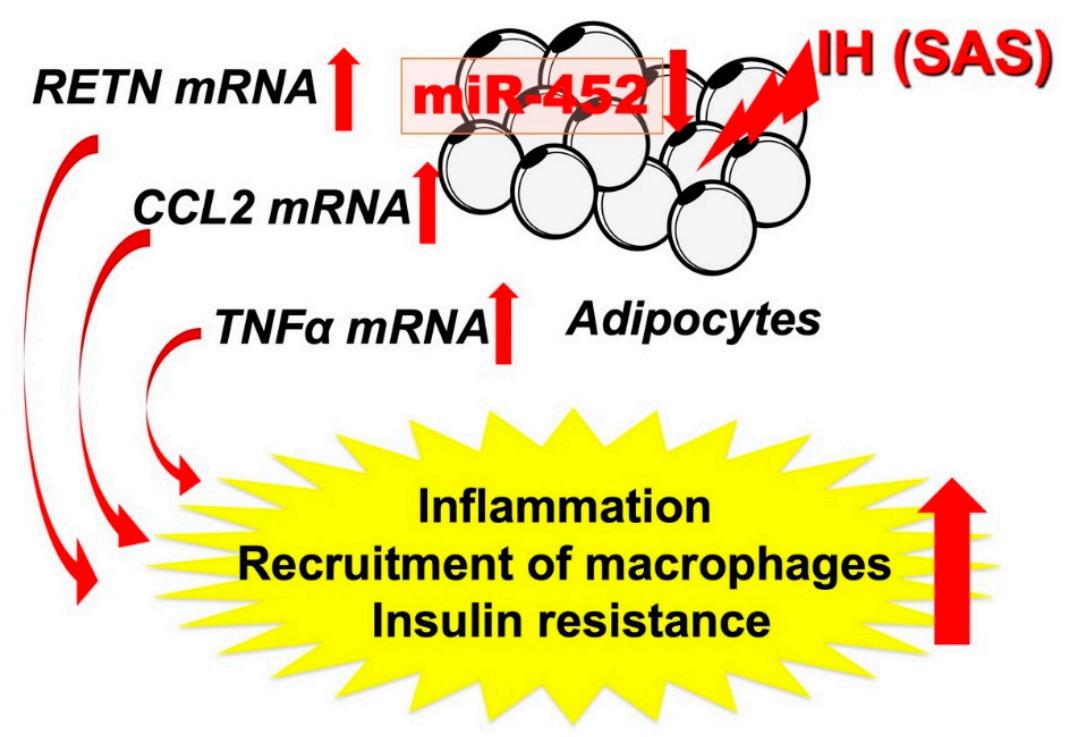

Figure 2. IH-induced increases in RETN, TNF $\alpha$, and CCL2 via downregulates the miR-452 in adipocytes. It is suggested that, in SAS patients, the upregulation of RETN, TNF $\alpha$, and CCL2 [7] may induce a proinflammatory phenotype of the adipose tissue, leading to the development of insulin resistance and reduced insulin sensitivity, and miR-452 could play crucial roles in the regulation of these gene expressions. Red up and down arrows mean increment and decrease, respectively. 


\subsection{Intermittent Hypoxia and Myokines}

Myokines, a comprehensive term for cytokines secreted by skeletal muscle, are released from skeletal muscle during muscle contraction $[8,86]$. The roles of myokines are diverse and include metabolic regulation, anti-inflammatory effects, and the regulation of skeletal muscle mass during injury regeneration $[8,87]$. Myokines include proteins, microRNA (miRNA)s, and exosomes, and hundreds of them have been found, but only a few of their biological functions have been elucidated. These myokines exhibit autocrine/paracrine and endocrine effects and may mediate the beneficial effects of exercise on other major organs involved in the regulation of energy homeostasis [87,88]. Adipose tissue appears to be an important target for myokines, which regulate energy flux and fuel supply during muscle contraction [8,87]. IL-6 was the first myokine to be discovered, and the level of circulating IL-6 secreted by skeletal muscle is markedly elevated during exercise and muscle contraction. Some clinical studies have shown that IL-6 is needed to reduce visceral adipose tissue during exercise [89], which in turn may lead to improved insulin resistance. Park T.J. et al. found that myonectin (MN) inhibits adipogenesis in 3T3-L1 preadipocytes by downregulating the expression of adipogenic transcription factors such as CCAAT/enhancer binding protein (C/EBP) $\alpha, \beta$, and peroxisome proliferator-activated receptor (PPAR) $\gamma$. Furthermore, they showed that MN has an inhibitory effect on adipogenesis through the regulation of the p38 mitogen-activated protein kinase (MAPK) pathway and $\mathrm{C} / \mathrm{EBP}$ homologous protein (CHOP). These results suggest that $\mathrm{MN}$ may be a new therapeutic target for obesity prevention [90] and required for metabolic homeostasis [91]. In addition, there are various other myokines that are secreted by skeletal muscle and influence pancreatic, hepatic, and adipose tissue and that are thought to affect glucose tolerance through various mechanisms. Many myokines act not only on other organs but also on themselves (autocrine), leading to the hypertrophy of skeletal muscle and increased insulin sensitivity (increased glucose uptake). Myokines such as myostatin, on the other hand, act on the self (autocrine), causing a decrease in skeletal muscle mass, worsening insulin resistance and promoting fat deposition in the liver [8]. Myokines are involved in the anti-inflammatory effects of physical activity and counteract the metabolic abnormalities of insulin resistance and diabetes $[92,93]$. Therefore, abnormalities in myokine secretion and function may have a direct influence on the worsening of insulin resistance. However, the mechanism by which myokines affect insulin resistance has not been fully elucidated [87,92-94].

Moreover, few studies have examined the direct effect of IH on myokine secretion. Otaka et al. examined the role of $\mathrm{MN}$ in myocardial ischemic injury by using knockout mice subjected to I/R conditions and found that $\mathrm{MN}$ increased cardiac dysfunction, apoptosis, and inflammatory gene expression more than with wild-type mice. On the other hand, transgenic mice overexpressing $\mathrm{MN}$ showed less myocardial damage after $\mathrm{I} / \mathrm{R}$, indicating that $\mathrm{MN}$ functions as an endurance exercise-induced myokine and ameliorates acute myocardial ischemic injury by suppressing apoptosis and inflammation in the heart [95]. $I / R$ is characterized by a limited blood supply to the organs and subsequent tissue damage as a result of recovery. Many studies have shown that inflammation associated with I/ $R$ injury can exacerbate myocardial damage [96], which may cause a condition experimentally similar to IH. On the basis of these studies [97], we suspected that IH had a direct effect on myokine secretion and conducted the following experiments. We investigated the changes in myokine levels and their regulation mechanisms by IH [19]. From our study, IH exposure increases IL-8, ON (osteonectin), and MN mRNA levels in mammalian muscle cells and octamer binding transcription factor 1 (OCT1) is a key factor for the IH-induced upregulation of IL-8 and MN mRNA expression levels and that nuclear factor erythroid 2-related factor 2 (NRF2) serves as an essential factor for the IH-induced upregulation of ON mRNA expression [31] (Figure 3). No other study has examined the direct relationship between myokine and $\mathrm{IH}$; therefore, further research is desirable. 


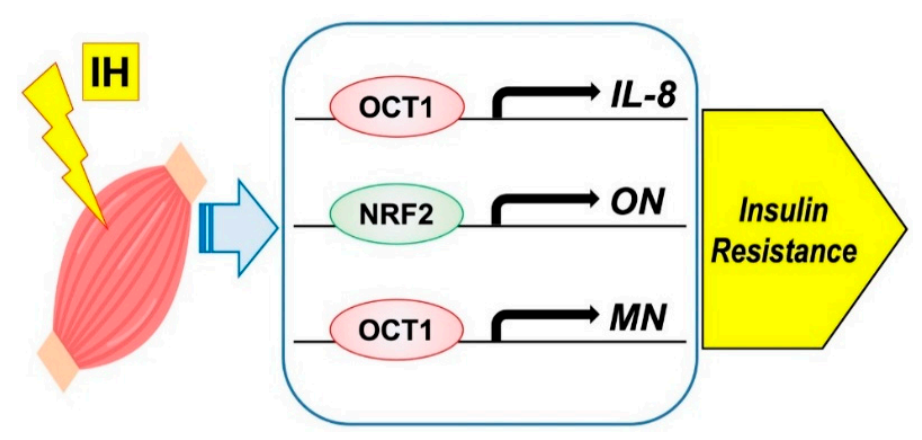

Figure 3. Possible mechanism on $\mathrm{IH}$-induced insulin resistance via myokine expression in muscle cells. IH significantly increased the mRNA levels of $I L-8, O N$, and MN. The promoters contain consensus transcription factor binding sequences Figure 1 in $I L-8$ and $M N$, and for NRF2 in $O N$, respectively.

Cardiomyokines are proteins secreted by a healthy or a diseased heart, and they perform a beneficial autocrine/paracrine function [98-100]. A search of PubMed (https:// pubmed.ncbi.nlm.nih.gov/) (accessed on 1 November 2021) for "cardiomyokine" turned up only six articles. We exposed rat $\mathrm{H} 9 \mathrm{c} 2$ cardiomyocytes and DMSO-induced cardiomyocytic differentiated mouse P19.CL6 cells to normoxia, IH, or SH for $24 \mathrm{~h}$. We measured the mRNA levels of several kinds of cytokines and Reg family genes because Reg family genes were reportedly expressed under acute ischemic conditions in rat and human heart [101]. IH significantly increased the mRNA levels of Reg IV and hepatocyte growth factor (Hgf) in the cardiomyocytes, and the gene expression of Reg IV and Hgf was increased via downregulation of the miR-499 level in IH-treated cardiomyocytes. It is suggested that, in SAS patients, the upregulation of Reg IV and Hgf may function against the apoptosis of cardiomyocytes, leading to the maintenance of cardiac functions, and that miR-499 could play crucial roles in the regulation of these gene expressions [102].

\section{Differences in Experimental IH Conditions In Vitro and In Vivo}

Experimental models of $\mathrm{IH}$, both in vitro and in vivo, include a variety of oxygen concentrations and exposure times. We and others have previously reported that the magnitude of IH expressed by $\mathrm{SpO}_{2}$ fluctuates between $75-98 \%$ and $50-80 \%$ in SAS $[17,103,104]$, which is almost equivalent to the medium condition in our studies. Under our experimental ' $\mathrm{IH}$ ' or 'normoxia' condition, cells were exposed either to $\mathrm{IH}\left(5 \mathrm{~min}\left[5 \% \mathrm{CO}_{2} 1 \% \mathrm{O}_{2}\right] / 10 \mathrm{~min}\right.$ $\left[5 \% \mathrm{CO}_{2} 21 \% \mathrm{O}_{2}\right]$ ) or normoxia for $24 \mathrm{~h}[5,7,19,25,32]$. Several papers have been published that attempt to elucidate the $\mathrm{IH}$ mechanism using cell culture, but the $\mathrm{IH}$ exposure regimen has been arbitrary. The oxygen concentration of cells exposed to $\mathrm{IH}$ varies from $1 \%$ to $5 \%$, and the exposure time varies from $30 \mathrm{~s}$ to $5 \mathrm{~min}$; the oxygen concentration of normoxia is generally $16-21 \%$, and the exposure time is $5-10 \mathrm{~min}$. The conditions are set to repeat $\mathrm{IH}$ and normoxia for 4 to $48 \mathrm{~h}[77,105-107]$. We recognize that the cell culture model of IH is different from the pattern of IH seen in OSAS patients in terms of the duration and frequency of episodes. Furthermore, it is very difficult to accurately reproduce $\mathrm{IH}$ in OSAS patients, and specifically, the level of intracellular oxygenation during apnea is unknown [77]. On the other hand, in vivo models of IH are being established that more closely resemble actual SAS conditions in humans. In in vivo, using mainly rats and mice, the oxygen concentration under IH conditions is often $5-12.5 \%$, while that under normoxia is $21 \%$, and $\mathrm{IH}$ and normoxia are repeated for $30 \mathrm{~s}$ each. Alternatively, IH is employed for $20 \mathrm{~s}$, followed by a $5 \%$ oxygen concentration for $15 \mathrm{~s}$ and then rapid reoxygenation to room air levels. In most cases, IH is performed for 8-12 h per day and normoxia for 12-16 h per day, and the total number of days varies slightly from 6 to 24 weeks depending on the experiment $[69,108,109]$. Thus, in vivo experiments were conducted under conditions more similar to SAS.

The actual changes in oxygen levels in peripheral organs when animals are exposed to IH conditions are shown; hypoxia-reoxygenation occurs in response to IH exposure in the liver, adipose tissue, and skeletal muscle, which we review here [12,110]. Reinke et al. 
revealed the pattern of oxygen variability in various tissues during intermittent hypoxia. They found that hypoxia-reoxygenation occurs in the liver and skeletal muscle, while white adipose tissue shows slightly less amplitude and continuous hypoxia (thought to be due to relatively poor perfusion of adipocytes). They clarified the oxygenation of peripheral organs and established an in vivo IH model [12].

\section{Intermittent Hypoxia and Inflammatory Cytokines}

In this review, we focus on the changes in cytokine expression under IH exposure, which suggest that inflammatory cytokines such as TNF- $\alpha$ and interleukins may be involved. It is thought that inflammation mediated by adipose tissue is particularly important in increasing insulin resistance in SAS patients $[70,111,112]$. However, inflammation in the liver, vascular endothelium, pancreas, and skeletal muscle was also implicated, suggesting that inflammation in these organs via cytokine secretion may exacerbate insulin resistance (Figure 4). The interactive effects of inflammatory cytokines secreted by each organ remain unclear, and further research is needed to clarify the mechanism of systemic inflammation. Furthermore, epigenetic mechanisms have been reported to induce inflammation under $\mathrm{IH}$, including our results $[5,7]$. MiRNAs with altered expression levels in SAS patients have been reviewed by Chen et al., and their target genes are transcription factors, protein kinases, and proinflammatory cytokines [27]. However, the detailed mechanism of miRNA involvement in inflammation caused by $\mathrm{IH}$ exposure remains unclear [35], and further research is desirable.

\section{Conclusions}

In this review, we discussed the pathogenesis of $\mathrm{IH}$, mainly in adipose tissue, the liver, and skeletal muscle, which leads to abnormal cytokine secretion and is associated with glucose intolerance (Figure 4). Abnormalities in cytokine secretion from the pancreas and vascular endothelium under IH conditions have also been studied [105,109,113], suggesting that IH exacerbates insulin resistance through a variety of complex mechanisms in various organs of the body.

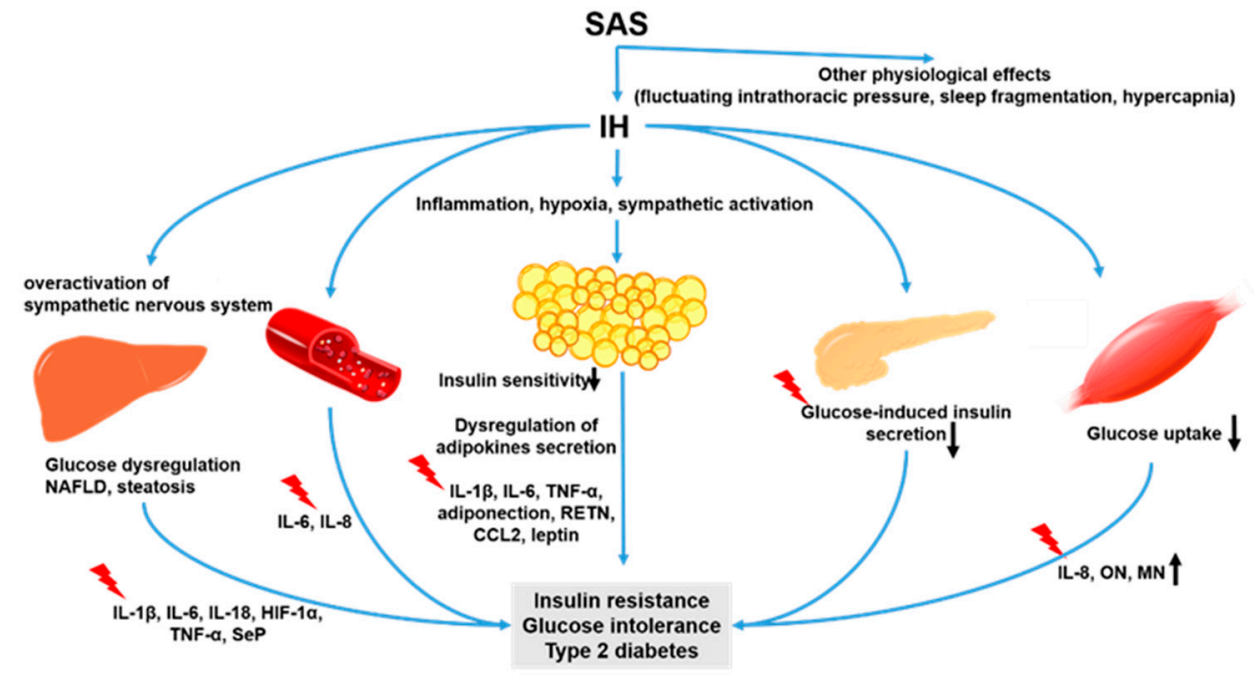

Figure 4. IH-induced dysfunctions in adipose tissues, skeletal muscle cells, and hepatocytes. Adipose tissues, skeletal muscle, and the liver are the main endocrine organs producing adipokines, myokines, and hepatokines, respectively. IH stimuli induce the expression/secretion of cytokines, which induce and/or worsen insulin resistance, glucose intolerance, and T2DM in adipocytes, skeletal muscle cells, and hepatocytes. IH also inhibits glucose-induced insulin secretion via the downregulation of CD38 [22] and vascular smooth muscle proliferation via IL-6-induced epiregulin expression [23,114]. IH promoted the production of TNF- $\alpha$, IL- $1 \beta$, and IL- 6 and caused inflammation and cell apoptosis in pancreatic tissue via the MAPK signaling pathway [109]. Black up and down arrows mean increment and decrease, respectively. 
Author Contributions: Conceptualization: T.U., manuscript writing-original draft: T.U., manuscript writing-review and editing: H.O., C.O. and S.T. All authors have read and agreed to the published version of the manuscript.

Funding: This research was supported in part by Grant-in-Aid for Scientific Research from the Ministry of Education, Culture, Sports, Science and Technology, Japan (grant numbers 08102003 , 15K19425, 18K15067 and 21K15389) and Japan Society for the Promotion of Science, and Japan Science and Technology Agency.

Institutional Review Board Statement: Not applicable.

Informed Consent Statement: Not applicable.

Acknowledgments: We thank all of the past and present colleagues for their contributions to the studies described herein, especially Asako Itaya-Hironaka, Akiyo Yamauchi, Mai Makino, Sumiyo Sakuramoto-Tsuchida, Ryogo Shobatake, Fumi Okada, and Maiko Takeda.

Conflicts of Interest: The authors declare no conflict of interest.

\section{Abbreviations}

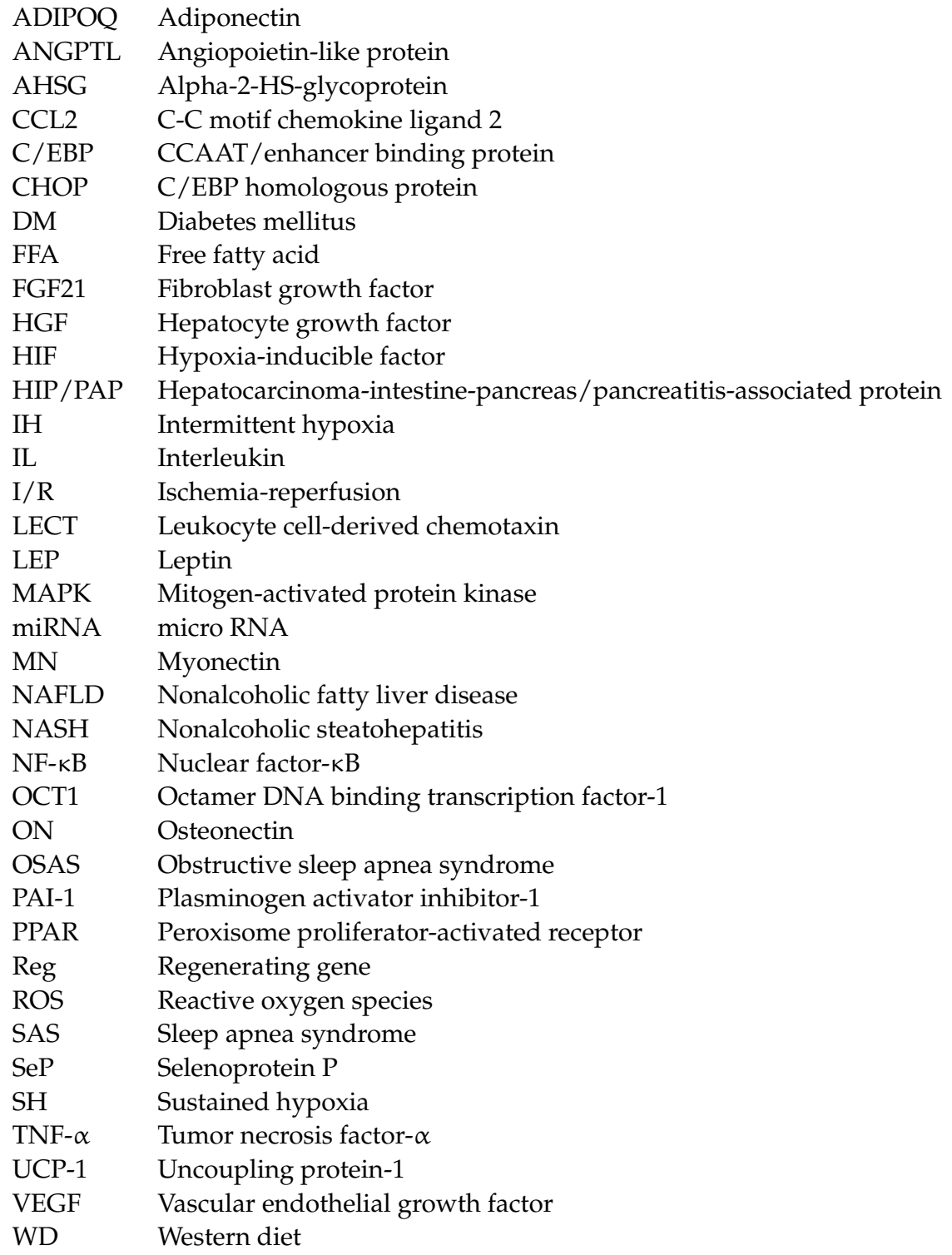




\section{References}

1. Peppard, P.E.; Young, T.; Barnet, J.H.; Palta, M.; Hagen, E.W.; Hla, K.M. Increased prevalence of sleep-disordered breathing in adults. Am. J. Epidemiol. 2013, 177, 1006-1014. [CrossRef]

2. Senaratna, C.V.; Perret, J.L.; Lodge, C.J.; Lowe, A.J.; Campbell, B.E.; Matheson, M.C.; Hamilton, G.S.; Dharmage, S.C. Prevalence of obstructive sleep apnea in the general population: A systematic review. Sleep Med. Rev. 2017, 34, 70-81. [CrossRef] [PubMed]

3. Mesarwi, O.A.; Loomba, R.; Malhotra, A. Obstructive sleep apnea, hypoxia, and nonalcoholic fatty liver disease. Am. J. Respir. Crit. Care Med. 2019, 199, 830-841. [CrossRef]

4. Kyotani, Y.; Takasawa, S.; Yoshizumi, M. Proliferative pathways of vascular smooth muscle cells in response to intermittent hypoxia. Int. J. Mol. Sci. 2019, 20, 2706. [CrossRef] [PubMed]

5. Uchiyama, T.; Ota, H.; Itaya-Hironaka, A.; Shobatake, R.; Yamauchi, A.; Sakuramoto-Tsuchida, S.; Makino, M.; Kimura, H.; Takeda, M.; Ohbayashi, C.; et al. Up-regulation of selenoprotein P and HIP/PAP mRNAs in hepatocytes by intermittent hypoxia via down-regulation of miR-203. Biochem. Biophys. Rep. 2017, 11, 130-137. [CrossRef]

6. Uchiyama, T.; Itaya-Hironaka, A.; Yamauchi, A.; Makino, M.; Sakuramoto-Tsuchida, S.; Shobatake, R.; Ota, H.; Takeda, M.; Ohbayashi, C.; Takasawa, S. Intermittent hypoxia up-regulates CCL2, RETN, and TNF $\alpha$ mRNAs in adipocytes via down-regulation of miR-452. Int. J. Mol. Sci. 2019, 20, 1960. [CrossRef]

7. Ota, H.; Fujita, Y.; Yamauchi, M.; Muro, S.; Kimura, H.; Takasawa, S. Relationship between intermittent hypoxia and Type 2 diabetes in sleep apnea syndrome. Int. J. Mol. Sci. 2019, 20, 4756. [CrossRef]

8. de Oliveira Dos Santos, A.R.; de Oliveira Zanuso, B.; Miola, V.F.B.; Barbalho, S.M.; Santos Bueno, P.C.; Flato, U.A.P.; Detregiachi, C.R.P.; Buchaim, D.V.; Buchaim, R.L.; Tofano, R.J.; et al. Adipokines, myokines, and hepatokines: Crosstalk and metabolic repercussions. Int. J. Mol. Sci. 2021, 22, 2639. [CrossRef]

9. Lee, J.J.; Sundar, K.M. Evaluation and management of adults with obstructive sleep apnea syndrome. Lung 2021, 199, 87-101. [CrossRef] [PubMed]

10. Tasali, E.; Ip, M.S. Obstructive sleep apnea and metabolic syndrome: Alterations in glucose metabolism and inflammation. Proc. Am. Thorac. Soc. 2008, 5, 207-217. [CrossRef] [PubMed]

11. Punjabi, N.M.; Beamer, B.A. Alterations in glucose disposal in sleep-disordered breathing. Am. J. Respir. Crit. Care Med. 2009, 179, 235-240. [CrossRef] [PubMed]

12. Reinke, C.; Bevans-Fonti, S.; Drager, L.F.; Shin, M.K.; Polotsky, V.Y. Effects of different acute hypoxic regimens on tissue oxygen profiles and metabolic outcomes. J. Appl. Physiol. 2011, 111, 881-890. [CrossRef]

13. de Lima, F.F.; Mazzotti, D.R.; Tufik, S.; Bittencourt, L. The role inflammatory response genes in obstructive sleep apnea syndrome: A review. Sleep Breath. 2016, 20, 331-338. [CrossRef] [PubMed]

14. Reichmuth, K.J.; Austin, D.; Skatrud, J.B.; Young, T. Association of sleep apnea and type II diabetes: A population-based study. Am. J. Respir. Crit. Care Med. 2005, 172, 1590-1595. [CrossRef]

15. Tasali, E.; Mokhlesi, B.; Van Cauter, E. Obstructive sleep apnea and type 2 diabetes: Interacting epidemics. Chest 2008, 133, 496-506. [CrossRef] [PubMed]

16. Ryan, S. Adipose tissue inflammation by intermittent hypoxia: Mechanistic link between obstructive sleep apnoea and metabolic dysfunction. J. Physiol. 2017, 595, 2423-2430. [CrossRef]

17. Michalek-Zrabkowska, M.; Macek, P.; Martynowicz, H.; Gac, P.; Mazur, G.; Grzeda, M.; Poreba, R. Obstructive sleep apnea as a risk factor of insulin resistance in nondiabetic adults. Life 2021, 11, 50. [CrossRef]

18. Song, S.O.; He, K.; Narla, R.R.; Kang, H.G.; Ryu, H.U.; Boyko, E.J. Metabolic consequences of obstructive sleep apnea especially pertaining to diabetes mellitus and insulin sensitivity. Diabetes Metab. J. 2019, 43, 144-155. [CrossRef]

19. Akasaka, J.; Naruse, K.; Sado, T.; Uchiyama, T.; Makino, M.; Yamauchi, A.; Ota, H.; Sakuramoto-Tsuchida, S.; Itaya-Hironaka, A.; Takasawa, S.; et al. Involvement of receptor for advanced glycation endproducts in hypertensive disorders of pregnancy. Int. J. Mol. Sci. 2019, 20, 5462. [CrossRef]

20. Muraki, I.; Tanigawa, T.; Yamagishi, K.; Sakurai, S.; Ohira, T.; Imano, H.; Kitamura, A.; Kiyama, M.; Sato, S.; Shimamoto, T.; et al. Nocturnal intermittent hypoxia and the development of type 2 diabetes: The circulatory risk in communities study (CIRCS). Diabetologia 2010, 53, 481-488. [CrossRef]

21. Briançon-Marjollet, A.; Monneret, D.; Henri, M.; Joyeux-Faure, M.; Totoson, P.; Cachot, S.; Faure, P.; Godin-Ribuot, D. Intermittent hypoxia in obese Zucker rats: Cardiometabolic and inflammatory effects. Exp. Physiol. 2016, 101, 1432-1442. [CrossRef]

22. Ota, H.; Tamaki, S.; Itaya-Hironaka, A.; Yamauchi, A.; Sakuramoto-Tsuchida, S.; Morioka, T.; Takasawa, S.; Kimura, H. Attenuation of glucose-induced insulin secretion by intermittent hypoxia via down-regulation of CD38. Life Sci. 2012, 90, 206-211. [CrossRef]

23. Kyotani, Y.; Ota, H.; Itaya-Hironaka, A.; Yamauchi, A.; Sakuramoto-Tsuchida, S.; Zhao, J.; Ozawa, K.; Nagayama, K.; Ito, S.; Takasawa, S.; et al. Intermittent hypoxia induces the proliferation of rat vascular smooth muscle cell with the increases in epidermal growth factor family and erbB2 receptor. Exp. Cell Res. 2013, 319, 3042-3050. [CrossRef]

24. Ota, H.; Itaya-Hironaka, A.; Yamauchi, A.; Sakuramoto-Tsuchida, S.; Miyaoka, T.; Fujimura, T.; Tsujinaka, H.; Yoshimoto, K.; Nakagawara, K.; Tamaki, S.; et al. Pancreatic $\beta$ cell proliferation by intermittent hypoxia via up-regulation of Reg family genes and HGF gene. Life Sci. 2013, 93, 664-672. [CrossRef] [PubMed]

25. Shobatake, R.; Itaya-Hironaka, A.; Yamauchi, A.; Makino, M.; Sakuramoto-Tsuchida, S.; Uchiyama, T.; Ota, H.; Takahashi, N.; Ueno, S.; Sugie, K.; et al. Intermittent hypoxia up-regulates gene expressions of peptide YY (PYY), glucagon-like peptide-1 (GLP-1), and neurotensin (NTS) in enteroendocrine cells. Int. J. Mol. Sci. 2019, 20, 1849. [CrossRef] 
26. Liu, Y.; Zou, J.; Li, X.; Zhao, X.; Zou, J.; Liu, S.; Meng, L.; Qian, Y.; Xu, H.; Yi, H.; et al. Effect of the interaction between obstructive sleep apnea and lipoprotein(a) on insulin resistance: A large-scale cross-sectional study. J. Diabetes Res. 2019, $2019,9583286$. [CrossRef]

27. Chen, Y.C.; Hsu, P.Y.; Hsiao, C.C.; Lin, M.C. Epigenetics: A potential mechanism involved in the pathogenesis of various adverse consequences of obstructive sleep apnea. Int. J. Mol. Sci. 2019, 20, 2937. [CrossRef] [PubMed]

28. Kawai, T.; Autieri, M.V.; Scalia, R. Adipose tissue inflammation and metabolic dysfunction in obesity. Am. J. Physiol. Cell Physiol. 2021, 320, C375-C391. [CrossRef]

29. Feijóo-Bandín, S.; Aragón-Herrera, A.; Moraña-Fernández, S.; Anido-Varela, L.; Tarazón, E.; Roselló-Lletí, E.; Portolés, M.; Moscoso, I.; Gualillo, O.; González-Juanatey, J.R.; et al. Adipokines and inflammation: Focus on cardiovascular diseases. Int. J. Mol. Sci. 2020, 21, 7711. [CrossRef] [PubMed]

30. Ryan, S.; Arnaud, C.; Fitzpatrick, S.F.; Gaucher, J.; Tamisier, R.; Pépin, J.L. Adipose tissue as a key player in obstructive sleep apnoea. Eur. Respir. Rev. 2019, 28, 190006. [CrossRef]

31. Takasawa, S.; Shobatake, R.; Itaya-Hironaka, A.; Makino, M.; Sakuramoto-Tsuchida, S.; Uchiyama, T.; Ota, H.; Yamauchi, A Up-regulation of IL-8, osteonectin, and myonectin mRNAs by intermittent hypoxia via OCT1- and NRF2-mediated mechanisms in skeletal muscle cells. Diabetologia 2020, 63 (Suppl. S1), 453.

32. Shobatake, R.; Takasawa, K.; Ota, H.; Itaya-Hironaka, A.; Yamauchi, A.; Sakuramoto-Tsuchida, S.; Uchiyama, T.; Makino, M.; Sugie, K.; Takasawa, S.; et al. Up-regulation of POMC and CART mRNAs by intermittent hypoxia via GATA transcription factors in human neuronal cells. Int. J. Biochem. Cell Biol. 2018, 95, 100-107. [CrossRef]

33. Maniaci, A.; Iannella, G.; Cocuzza, S.; Vicini, C.; Magliulo, G.; Ferlito, S.; Cammaroto, G.; Meccariello, G.; De Vito, A.; Nicolai, A.; et al. Oxidative stress and inflammation biomarker expression in obstructive sleep apnea patients. J. Clin. Med. 2021, 10, 277. [CrossRef] [PubMed]

34. Wang, Y.; Meagher, R.B.; Ambati, S.; Cheng, H.; Ma, P.; Phillips, B.G. Patients with obstructive sleep apnea have altered levels of four cytokines associated with cardiovascular and kidney disease, but near normal levels with airways therapy. Nat. Sci. Sleep 2021, 13, 457-466. [CrossRef]

35. Chen, Y.C.; Hsu, P.Y.; Su, M.C.; Chin, C.H.; Liou, C.W.; Wang, T.Y.; Lin, Y.Y.; Lee, C.P.; Lin, M.C.; Hsiao, C.C. miR-21-5p under-expression in patients with obstructive sleep apnea modulates intermittent hypoxia with re-oxygenation-induced-cell apoptosis and cytotoxicity by targeting pro-inflammatory TNF- $\alpha$-TLR4 signaling. Int. J. Mol. Sci. 2020, 21, 999. [CrossRef]

36. In, S.M.; Park, D.Y.; Lee, K.I.; Gu, G.; Kim, H.J. The effects of intermittent hypoxia on human nasal mucosa. Sleep Breath. 2021, 25, 1453-1460. [CrossRef]

37. Du, Y.; Wang, X.; Li, L.; Hao, W.; Zhang, H.; Li, Y.; Qin, Y.; Nie, S.; Christopher, T.A.; Lopez, B.L.; et al. miRNA-mediated suppression of a cardioprotective cardiokine as a novel mechanism exacerbating post-MI remodeling by sleep breathing disorders. Circ. Res. 2020, 126, 212-228. [CrossRef] [PubMed]

38. Kimura, H.; Ota, H.; Kimura, Y.; Takasawa, S. Effects of intermittent hypoxia on pulmonary vascular and systemic diseases. Int. J. Environ. Res. Public Health 2019, 16, 3101. [CrossRef]

39. Eslam, M.; Valenti, L.; Romeo, S. Genetics and epigenetics of NAFLD and NASH: Clinical impact. J. Hepatol. 2018, 68, 268-279. [CrossRef]

40. Aron-Wisnewsky, J.; Clement, K.; Pepin, J.L. Nonalcoholic fatty liver disease and obstructive sleep apnea. Metabolism 2016, 65, 1124-1135. [CrossRef]

41. Friedman, S.L.; Neuschwander-Tetri, B.A.; Rinella, M.; Sanyal, A.J. Mechanisms of NAFLD development and therapeutic strategies. Nat. Med. 2018, 24, 908-922. [CrossRef]

42. Nobili, V.; Cutrera, R.; Liccardo, D.; Pavone, M.; Devito, R.; Giorgio, V.; Verrillo, E.; Baviera, G.; Musso, G. Obstructive sleep apnea syndrome affects liver histology and inflammatory cell activation in pediatric nonalcoholic fatty liver disease, regardless of obesity/insulin resistance. Am. J. Respir. Crit. Care Med. 2014, 189, 66-76. [CrossRef] [PubMed]

43. Kang, H.H.; Kim, I.K.; Lee, H.I.; Joo, H.; Lim, J.U.; Lee, J.; Lee, S.H.; Moon, H.S. Chronic intermittent hypoxia induces liver fibrosis in mice with diet-induced obesity via TLR4/MyD88/MAPK/NF-kB signaling pathways. Biochem. Biophys. Res. Commun. 2017, 490, 349-355. [CrossRef]

44. Jullian-Desayes, I.; Trzepizur, W.; Boursier, J.; Joyeux-Faure, M.; Bailly, S.; Benmerad, M.; Le Vaillant, M.; Jaffre, S.; Pigeanne, T.; Bizieux-Thaminy, A.; et al. Obstructive sleep apnea, chronic obstructive pulmonary disease and NAFLD: An individual participant data meta-analysis. Sleep Med. 2021, 77, 357-364. [CrossRef]

45. Savransky, V.; Bevans, S.; Nanayakkara, A.; Li, J.; Smith, P.L.; Torbenson, M.S.; Polotsky, V.Y. Chronic intermittent hypoxia causes hepatitis in a mouse model of diet-induced fatty liver. Am. J. Physiol. Gastrointest. Liver Physiol. 2007, 293, G871-G877. [CrossRef] [PubMed]

46. Zhou, J.; Zhao, Y.; Guo, Y.J.; Zhao, Y.S.; Liu, H.; Ren, J.; Li, J.R.; Ji, E.S. A rapid juvenile murine model of nonalcoholic steatohepatitis (NASH): Chronic intermittent hypoxia exacerbates western diet-induced NASH. Life Sci. 2021, 276, 119403. [CrossRef]

47. Paschetta, E.; Belci, P.; Alisi, A.; Liccardo, D.; Cutrera, R.; Musso, G.; Nobili, V. OSAS-related inflammatory mechanisms of liver injury in nonalcoholic fatty liver disease. Mediat. Inflamm. 2015, 2015, 815721. [CrossRef]

48. Mesarwi, O.A.; Moya, E.A.; Zhen, X.; Gautane, M.; Zhao, H.; Wegbrans Giró, P.; Alshebli, M.; McCarley, K.E.; Breen, E.C.; Malhotra, A. Hepatocyte HIF-1 and intermittent hypoxia independently impact liver fibrosis in murine NAFLD. Am. J. Respir. Cell Mol. Biol. 2021, 65, 390-402. [CrossRef] 
49. Barros, D.; García-Río, F. Obstructive sleep apnea and dyslipidemia: From animal models to clinical evidence. Sleep 2019, 42, 1-15. [CrossRef] [PubMed]

50. Jensen-Cody, S.O.; Potthoff, M.J. Hepatokines and metabolism: Deciphering communication from the liver. Mol. Metab. 2021, 44, 101138. [CrossRef]

51. Misu, H. Identification of hepatokines involved in pathology of type 2 diabetes and obesity. Endocr. J. 2019, 66, 659-662. [CrossRef] [PubMed]

52. Burk, R.F.; Hill, K.E. Selenoprotein P: An extracellular protein with unique physical characteristics and a role in selenium homeostasis. Annu. Rev. Nutr. 2005, 25, 215-235. [CrossRef]

53. Takasawa, S. Regenerating gene (REG) product and its potential clinical usage. Expert Opin. Ther. Targets 2016, 20, 541-550. [CrossRef] [PubMed]

54. Terazono, K.; Yamamoto, H.; Takasawa, S.; Shiga, K.; Yonemura, Y.; Tochino, Y.; Okamoto, H. A novel gene activated in regenerating islets. J. Biol. Chem. 1988, 263, 2111-2114. [CrossRef] [PubMed]

55. Okamoto, H.; Takasawa, S. Okamoto model for necrosis and its expansions, CD38-cyclic ADP-ribose signal system for intracellular $\mathrm{Ca}^{2+}$ mobilization and Reg ([Regenerating gene] protein)-Reg receptor system for cell regeneration. Proc. Jpn. Acad. Ser. B Phys. Biol. Sci. 2021, 79, 423-461. [CrossRef] [PubMed]

56. Shervani, N.J.; Takasawa, S.; Uchigata, Y.; Akiyama, T.; Nakagawa, K.; Noguchi, N.; Takada, H.; Takahashi, I.; Yamauchi, A.; Ikeda, T.; et al. Autoantibodies to REG, a beta-cell regeneration factor, in diabetic patients. Eur. J. Clin. Investig. 2004, 34, 752-758. [CrossRef]

57. Watanabe, T.; Yonemura, Y.; Yonekura, H.; Suzuki, Y.; Miyashita, H.; Sugiyama, K.; Moriizumi, S.; Unno, M.; Tanaka, O.; Kondo, H.; et al. Pancreatic beta-cell replication and amelioration of surgical diabetes by Reg protein. Proc. Natl. Acad. Sci. USA 1994, 91, 3589-3592. [CrossRef]

58. Lasserre, C.; Christa, L.; Simon, M.T.; Vernier, P.; Bréchot, C. A novel gene (HIP) activated in human primary liver cancer. Cancer Res. 1992, 52, 5089-5095. [PubMed]

59. Orelle, B.; Keim, V.; Masciotra, L.; Dagorn, J.C.; Iovanna, J.L. Human pancreatitis-associated protein. Messenger RNA cloning and expression in pancreatic diseases. J. Clin. Investig. 1992, 90, 2284-2291. [CrossRef]

60. Lieu, H.T.; Batteux, F.; Simon, M.T.; Cortes, A.; Nicco, C.; Zavala, F.; Pauloin, A.; Tralhao, J.G.; Soubrane, O.; Weill, B.; et al. HIP/PAP accelerates liver regeneration and protects against acetaminophen injury in mice. Hepatology 2005, 42, 618-626. [CrossRef]

61. Gironella, M.; Folch-Puy, E.; LeGoffic, A.; Garcia, S.; Christa, L.; Smith, A.; Tebar, L.; Hunt, S.P.; Bayne, R.; Smith, A.J.; et al. Experimental acute pancreatitis in PAP/HIP knock-out mice. Gut 2007, 56, 1091-1097. [CrossRef] [PubMed]

62. Simon, M.T.; Pauloin, A.; Normand, G.; Lieu, H.T.; Mouly, H.; Pivert, G.; Carnot, F.; Tralhao, J.G.; Brechot, C.; Christa, L. HIP/PAP stimulates liver regeneration after partial hepatectomy and combines mitogenic and anti-apoptotic functions through the PKA signaling pathway. FASEB J. 2003, 17, 1441-1450. [CrossRef] [PubMed]

63. Takeda, Y.; Itaya-Hironaka, A.; Yamauchi, A.; Makino, M.; Sakuramoto-Tsuchida, S.; Ota, H.; Kawaguchi, R.; Takasawa, S. Intermittent hypoxia upregulates the renin and Cd38 mRNAs in renin-producing cells via the downregulation of miR-203. Int. J. Mol. Sci. 2021, 22, 10127. [CrossRef]

64. Jo, J.; Gavrilova, O.; Pack, S.; Jou, W.; Mullen, S.; Sumner, A.E.; Cushman, S.W.; Periwal, V. Hypertrophy and/or hyperplasia: Dynamics of adipose tissue growth. PLoS Comput. Biol. 2009, 5, e1000324. [CrossRef]

65. Jung, U.J.; Choi, M.S. Obesity and its metabolic complications: The role of adipokines and the relationship between obesity, inflammation, insulin resistance, dyslipidemia and nonalcoholic fatty liver disease. Int. J. Mol. Sci. 2014, 15, 6184-6223. [CrossRef] [PubMed]

66. Rajesh, Y.; Sarkar, D. Association of adipose tissue and adipokines with development of obesity-induced liver cancer. Int. J. Mol. Sci. 2021, 22, 2163. [CrossRef] [PubMed]

67. Trayhurn, P. Hypoxia and adipose tissue function and dysfunction in obesity. Physiol. Rev. 2013, 93, 1-21. [CrossRef]

68. Gileles-Hillel, A.; Almendros, I.; Khalyfa, A.; Nigdelioglu, R.; Qiao, Z.; Hamanaka, R.B.; Mutlu, G.M.; Akbarpour, M.; Gozal, D. Prolonged exposures to intermittent hypoxia promote visceral white adipose tissue inflammation in a murine model of severe sleep apnea: Effect of normoxic recovery. Sleep 2017, 40, zsw074. [CrossRef]

69. Poulain, L.; Thomas, A.; Rieusset, J.; Casteilla, L.; Levy, P.; Arnaud, C.; Dematteis, M. Visceral white fat remodelling contributes to intermittent hypoxia-induced atherogenesis. Eur. Respir. J. 2014, 43, 513-522. [CrossRef]

70. Murphy, A.M.; Thomas, A.; Crinion, S.J.; Kent, B.D.; Tambuwala, M.M.; Fabre, A.; Pepin, J.L.; Roche, H.M.; Arnaud, C.; Ryan, S. Intermittent hypoxia in obstructive sleep apnoea mediates insulin resistance through adipose tissue inflammation. Eur. Respir. J. 2017, 49, 1601731. [CrossRef]

71. Prabhakar, N.R.; Kumar, G.K. Mechanisms of sympathetic activation and blood pressure elevation by intermittent hypoxia. Respir. Physiol. Neurobiol. 2010, 174, 156-161. [CrossRef]

72. Li, Q.; Zhao, M.; Wang, Y.; Zhong, F.; Liu, J.; Gao, L.; Zhao, J. Associations between serum free fatty acid levels and incident diabetes in a 3-year cohort study. Diabetes Metab. Syndr. Obes. 2021, 14, 2743-2751. [CrossRef]

73. Lytrivi, M.; Castell, A.L.; Poitout, V.; Cnop, M. Recent insights into mechanisms of $\beta$-cell lipo- and glucolipotoxicity in Type 2 diabetes. J. Mol. Biol. 2020, 432, 1514-1534. [CrossRef] 
74. Benito-Vicente, A.; Jebari-Benslaiman, S.; Galicia-Garcia, U.; Larrea-Sebal, A.; Uribe, K.B.; Martin, C. Molecular mechanisms of lipotoxicity-induced pancreatic $\beta$-cell dysfunction. Int. Rev. Cell Mol. Biol. 2021, 359, 357-402. [CrossRef]

75. Gabryelska, A.; Karuga, F.F.; Szmyd, B.; Białasiewicz, P. HIF-1 $\alpha$ as a mediator of insulin resistance, T2DM, and its complications: Potential links with obstructive sleep apnea. Front. Physiol. 2020, 11, 1035. [CrossRef]

76. Gabryelska, A.; Szmyd, B.; Panek, M.; Szemraj, J.; Kuna, P.; Białasiewicz, P. Serum hypoxia-inducible factor-1 $\alpha$ protein level as a diagnostic marker of obstructive sleep apnea. Pol. Arch. Intern. Med. 2020, 130, 158-160. [CrossRef]

77. Ryan, S.; Taylor, C.T.; McNicholas, W.T. Selective activation of inflammatory pathways by intermittent hypoxia in obstructive sleep apnea syndrome. Circulation 2005, 112, 2660-2667. [CrossRef] [PubMed]

78. Korbecki, J.; Simińska, D.; Gassowska-Dobrowolska, M.; Listos, J.; Gutowska, I.; Chlubek, D.; Baranowska-Bosiacka, I. Chronic and cycling hypoxia: Drivers of cancer chronic inflammation through HIF-1 and NF-kB activation: A review of the molecular mechanisms. Int. J. Mol. Sci. 2021, 22, 10701. [CrossRef]

79. Reddy, S.; Amutha, A.; Rajalakshmi, R.; Bhaskaran, R.; Monickaraj, F.; Rangasamy, S.; Anjana, R.M.; Abhijit, S.; Gokulakrishnan, K.; Das, A.; et al. Association of increased levels of MCP-1 and cathepsin-D in young onset type 2 diabetes patients (T2DM-Y) with severity of diabetic retinopathy. J. Diabetes Complicat. 2017, 31, 804-809. [CrossRef] [PubMed]

80. Chuang, L.P.; Chen, N.H.; Lin, Y.; Ko, W.S.; Pang, J.H. Increased MCP-1 gene expression in monocytes of severe OSA patients and under intermittent hypoxia. Sleep Breath. 2016, 20, 425-433. [CrossRef] [PubMed]

81. Drager, L.F.; Li, J.; Shin, M.K.; Reinke, C.; Aggarwal, N.R.; Jun, J.C.; Bevans-Fonti, S.; Sztalryd, C.; O’Byrne, S.M.; Kroupa, O.; et al. Intermittent hypoxia inhibits clearance of triglyceride-rich lipoproteins and inactivates adipose lipoprotein lipase in a mouse model of sleep apnoea. Eur. Heart J. 2012, 33, 783-790. [CrossRef] [PubMed]

82. Ge, M.Q.; Yeung, S.C.; Mak, J.C.W.; Ip, M.S.M. Differential metabolic and inflammatory responses to intermittent hypoxia in substrains of lean and obese C57BL/ 6 mice. Life Sci. 2019, 238, 116959. [CrossRef]

83. Venkata, C.; Venkateshiah, S.B. Sleep-disordered breathing during pregnancy. J. Am. Board Fam. Med. 2009, 22, 158-168. [CrossRef]

84. Pengo, M.F.; Rossi, G.P.; Steier, J. Obstructive sleep apnea, gestational hypertension and preeclampsia: A review of the literature. Curr. Opin. Pulm. Med. 2014, 20, 588-594. [CrossRef]

85. Dominguez, J.E.; Street, L.; Louis, J. Management of obstructive sleep apnea in pregnancy. Obstet. Gynecol. Clin. N. Am. 2018, 45, 233-247. [CrossRef]

86. Oh, K.J.; Lee, D.S.; Kim, W.K.; Han, B.S.; Lee, S.C.; Bae, K.H. Metabolic adaptation in obesity and Type II diabetes: Myokines, adipokines and hepatokines. Int. J. Mol. Sci. 2016, 18, 8. [CrossRef] [PubMed]

87. Laurens, C.; Bergouignan, A.; Moro, C. Exercise-released myokines in the control of energy metabolism. Front. Physiol. 2020, 11, 91. [CrossRef]

88. Di Felice, V.; Coletti, D.; Seelaender, M. Editorial: Myokines, adipokines, cytokines in muscle pathophysiology. Front. Physiol. 2020, 11, 592856. [CrossRef] [PubMed]

89. Wedell-Neergaard, A.S.; Lang Lehrskov, L.; Christensen, R.H.; Legaard, G.E.; Dorph, E.; Larsen, M.K.; Launbo, N.; Fagerlind, S.R.; Seide, S.K.; Nymand, S.; et al. Exercise-induced changes in visceral adipose tissue mass are regulated by IL-6 signaling: A randomized controlled trial. Cell Metab. 2019, 29, 844-855. [CrossRef]

90. Park, T.J.; Park, A.; Kim, J.; Kim, J.Y.; Han, B.S.; Oh, K.J.; Lee, E.W.; Lee, S.C.; Bae, K.H.; Kim, W.K. Myonectin inhibits adipogenesis in 3T3-L1 preadipocytes by regulating p38 MAPK pathway. BMB Rep. 2021, 54, 124-129. [CrossRef] [PubMed]

91. Little, H.C.; Rodriguez, S.; Lei, X.; Tan, S.Y.; Stewart, A.N.; Sahagun, A.; Sarver, D.C.; Wong, G.W. Myonectin deletion promotes adipose fat storage and reduces liver steatosis. FASEB J. 2019, 33, 8666-8687. [CrossRef]

92. Eckel, J. Myokines in metabolic homeostasis and diabetes. Diabetologia 2019, 62, 1523-1528. [CrossRef]

93. Garneau, L.; Aguer, C. Role of myokines in the development of skeletal muscle insulin resistance and related metabolic defects in type 2 diabetes. Diabetes Metab. 2019, 45, 505-516. [CrossRef]

94. Atakan, M.M.; Koşar, Ş.N.; Güzel, Y.; Tin, H.T.; Yan, X. The role of exercise, diet, and cytokines in preventing obesity and improving adipose tissue. Nutrients 2021, 13, 1459. [CrossRef] [PubMed]

95. Otaka, N.; Shibata, R.; Ohashi, K.; Uemura, Y.; Kambara, T.; Enomoto, T.; Ogawa, H.; Ito, M.; Kawanishi, H.; Maruyama, S.; et al. Myonectin is an exercise-induced myokine that protects the heart from ischemia-reperfusion injury. Circ. Res. 2018, 123, 1326-1338. [CrossRef] [PubMed]

96. Yin, X.; Zheng, Y.; Zhai, X.; Zhao, X.; Cai, L. Diabetic inhibition of preconditioning- and postconditioning-mediated myocardial protection against ischemia/reperfusion injury. Exp. Diabetes Res. 2012, 2012, 198048. [CrossRef]

97. Szabó, M.R.; Pipicz, M.; Csont, T.; Csonka, C. Modulatory effect of myokines on reactive oxygen species in ischemia/reperfusion. Int. J. Mol. Sci. 2020, 21, 9382. [CrossRef] [PubMed]

98. Maciel, L.; de Oliveira, D.F.; Mesquita, F.; Souza, H.; Oliveira, L.; Christie, M.L.A.; Palhano, F.L.; Campos de Carvalho, A.C.; Nascimento, J.H.M.; Foguel, D. New cardiomyokine reduces myocardial ischemia/reperfusion injury by PI3K-AKT pathway via a putative KDEL-receptor binding. J. Am. Heart Assoc. 2021, 10, e019685. [CrossRef]

99. Maciel, L.; de Oliveira, D.F.; Verissimo da Costa, G.C.; Bisch, P.M.; Nascimento, J.H.M. Cardioprotection by the transfer of coronary effluent from ischaemic preconditioned rat hearts: Identification of cardioprotective humoral factors. Basic Res. Cardiol. 2017, 112, 52. [CrossRef]

100. Glembotski, C.C. Functions for the cardiomyokine, MANF, in cardioprotection, hypertrophy and heart failure. J. Mol. Cell. Cardiol. 2011, 51, 512-517. [CrossRef] 
101. Kiji, T.; Dohi, Y.; Takasawa, S.; Okamoto, H.; Nonomura, A.; Taniguchi, S. Activation of regenerating gene Reg in rat and human hearts in response to acute stress. Am. J. Physiol. Heart Circ. Physiol. 2005, 289, H277-H284. [CrossRef]

102. Takasawa, S.; Itaya-Hironaka, A.; Yamauchi, A.; Makino, M.; Sakuramoto-Tsuchida, S.; Uchiyama, T.; Takeda, Y.; Kyotani, Y.; Ota, H. Up-regulation of regenerating gene IV and hepatocyte growth factor in cardiomyocytes by intermittent hypoxia and its microRNA-mediated mechanism. Diabetes 2021, 70 (Suppl. S1), 378-P. [CrossRef]

103. Niijima, M.; Kimura, H.; Edo, H.; Shinozaki, T.; Kang, J.; Masuyama, S.; Tatsumi, K.; Kuriyama, T. Manifestation of pulmonary hypertension during REM sleep in obstructive sleep apnea syndrome. Am. J. Respir. Crit. Care Med. 1999, 159, 1766-1772. [CrossRef]

104. Ota, H.; Takasawa, S.; Yamauchi, M.; Yoshikawa, M.; Tomoda, K.; Kimura, H. Intermittent hypoxia in pancreatic beta cells. Pancreat. Disord. Ther. 2015, 5, S5. [CrossRef]

105. Polotsky, V.Y.; Savransky, V.; Bevans-Fonti, S.; Reinke, C.; Li, J.; Grigoryev, D.N.; Shimoda, L.A. Intermittent and sustained hypoxia induce a similar gene expression profile in human aortic endothelial cells. Physiol. Genom. 2010, 41, 306-314. [CrossRef]

106. Nanduri, J.; Wang, N.; Yuan, G.; Khan, S.A.; Souvannakitti, D.; Peng, Y.J.; Kumar, G.K.; Garcia, J.A.; Prabhakar, N.R. Intermittent hypoxia degrades HIF- $2 \alpha$ via calpains resulting in oxidative stress: Implications for recurrent apnea-induced morbidities. Proc. Natl. Acad. Sci. USA 2009, 106, 1199-1204. [CrossRef]

107. Magalang, U.J.; Cruff, J.P.; Rajappan, R.; Hunter, M.G.; Patel, T.; Marsh, C.B.; Raman, S.V.; Parinandi, N.L. Intermittent hypoxia suppresses adiponectin secretion by adipocytes. Exp. Clin. Endocrinol. Diabetes 2009, 117, 129-134. [CrossRef]

108. Badran, M.; Yassin, B.A.; Lin, D.T.S.; Kobor, M.S.; Ayas, N.; Laher, I. Gestational intermittent hypoxia induces endothelial dysfunction, reduces perivascular adiponectin and causes epigenetic changes in adult male offspring. J. Physiol. 2019, 597, 5349-5364. [CrossRef] [PubMed]

109. Wang, Y.; Hai, B.; Niu, X.; Ai, L.; Cao, Y.; Li, R.; Li, Y. Chronic intermittent hypoxia disturbs insulin secretion and causes pancreatic injury via the MAPK signaling pathway. Biochem. Cell Biol. 2017, 95, 415-420. [CrossRef] [PubMed]

110. Almendros, I.; Farré, R.; Planas, A.M.; Torres, M.; Bonsignore, M.R.; Navajas, D.; Montserrat, J.M. Tissue oxygenation in brain, muscle, and fat in a rat model of sleep apnea: Differential effect of obstructive apneas and intermittent hypoxia. Sleep 2011, 34, 1127-1133. [CrossRef] [PubMed]

111. Taylor, C.T.; Kent, B.D.; Crinion, S.J.; McNicholas, W.T.; Ryan, S. Human adipocytes are highly sensitive to intermittent hypoxia induced NF-kappaB activity and subsequent inflammatory gene expression. Biochem. Biophys. Res. Commun. 2014, 447, 660-665. [CrossRef] [PubMed]

112. Thorn, C.E.; Knight, B.; Pastel, E.; McCulloch, L.J.; Patel, B.; Shore, A.C.; Kos, K. Adipose tissue is influenced by hypoxia of obstructive sleep apnea syndrome independent of obesity. Diabetes Metab. 2017, 43, 240-247. [CrossRef] [PubMed]

113. Wang, Y.; Ai, L.; Hai, B.; Cao, Y.; Li, R.; Li, H.; Li, Y. Tempol alleviates chronic intermittent hypoxia-induced pancreatic injury through repressing inflammation and apoptosis. Physiol. Res. 2019, 68, 445-455. [CrossRef] [PubMed]

114. Kyotani, Y.; Itaya-Hironaka, A.; Yamauchi, A.; Sakuramoto-Tsuchida, S.; Makino, M.; Takasawa, S.; Yoshizumi, M. Intermittent hypoxia-induced epiregulin expression by IL-6 production in human coronary artery smooth muscle cells. FEBS Open Bio 2018, 8 , 868-876. [CrossRef] [PubMed] 